\title{
地球規模課題対応国際科学技術協力プログラム (SATREPS)
}

\section{研究課題別中間評価報告書}

\section{1 . 研究課題名}

「バイオマス・廃棄物資源のスーパークリーンバイオ燃料への触媒転換技術の開発」

( 2017 年 08月〜2022年 08月)

\section{2 . 研究代表者}

2. 1. 日本側研究代表者: 椿 範立 (富山大学 学術研究部工学系 教授)

2.2. 相手国側研究代表者: Thar apong Vitidsant（タイ王国 チュラロンコン大学 理学部

化学工学科 教授 / バイオマス燃料エネルギーセンター長)

\section{3 . 研究概要}

本研究課題は、幅広い非可食系バイオマス資源 (木質・農産残渣・廃棄物系) から、化石代替 (軽油・ガソリン・LPG 等代替) となる高品位バイオ燃料・化学品を製造する技術を実証すると ともに、事業化システムや製品利用方法等の社会実装提案を行うことを目指すものである。

プロジェクト目標は、これらのバイオマス資源を原料とする化石燃料代替技術か開発され、社 会実装の提案がなされることであり、上位目標は、この技術が民間企業の投資など社会実装の基 盤となり化石資源代替・地球温暖化対策の加速化に貢献することである。

日本側では研究代表機関の富山大学の他、(一財) 石炭エネルギーセンター、JXTG エネルギー (株)、(株) 巴商会、タイ国側ではチュラロンコン大学の他、北部再生可能エネルギー (株)、タ イ石油公社の共同研究体制によって、以下の3つの研究課題か実施されている:

(1) 各種バイオマス資源からの合成ガス製造技術開発

（2）触媒転換によるバイオ燃料製造技術の開発

(3) 利用技術・全体システム構築による社会実装提案

\section{4 . 評洒結果}

総合評価 : $A+$

(所期の計画をやや上回る取り組みが行われ、大きな成果か期待できる。)

当初計画から見た達成度は高く、小規模な設備トラブルにも適切に対応しながら非常に順調に 進捗している。既にいくつかの指標においては定量的目標を達成しているなど、中間段階として すぐれていると判断できる。特に触媒技術について、科学的先端性と汎用性が高い点を評価でき る。高付加価値のジェット燃料など、新たな方向性か検討されている点も評価できる。人材育成 も順調に進んでいる。 
本技術で開発中のバイオ燃料 (炭化水素、アルコール) は、高度なプロセスで合成されるため、 FAME (脂肪酸メチルエステル) など他のバイオ燃料と比較して高い品質か期待できるものの、 価格競争力に課題がある。プロセス・LCA 解析、システム検討の準備が開始されているが、今後 は、社会実装に向けた検討をさらに進めることか浗められる。

\section{4-1 . 国際共同研究の進捗状況について}

計画されたほとんどの機材がタイ側に供与され、実際に稼働している。特にベンチテスト装置 か完成し、ガス化工程、フィッシャー・トロプシュ (FT) 合成工程ともに、実ガス運転を行いバ イオディーゼル燃料の試作に成功するなど、順調に進捗しており、ガス化組成 ([H2]/[CO]比) 等 いくつかの開発目標 (指標) も既に達成されている。ガス化設備で技術的卜ラブルがいつか発 生したが、これらは研究開発につきものであり、適切に対処されたと評価できる。大筋として計 画通り進捗し、一部については当初の目標・計画以上に進捗しており、高く評価できる。

本プロジェクトにおいて、当初計画では想定されていなかった新たな展開は特に生じていない ものの、外部環境の変化としてプロジェクト開始以降原油価格の低下により社会実装に向けた価 格面でのハードルが高くなっているため、高付加価值のあるジェット燃料の開発などか検討され ている。一方で、研究代表者による新規な FT 合成触媒に関する顕著な研究成果は、触媒コス卜 の低減を通じて本プロジェクトの社会実装に資する可能性がある。

バイオ液体燃料は世界的に社会ニーズが高く、研究チームの有する高度な触媒技術をベースと した高いレベルの研究であり、成果の科学的・技術的インパクトはきわめて大きい。国内外の類 似研究と比較しても、カプセル型 FT 合成触媒、ジェット燃料を直接合成できる可能性のある才 ンデマンド触媒など非常に高いレベルにある。ガス化技術については標準的プロセスのひとつを 採用し手堅く構築したが、今後他のガス化プロセスも参考にしながら、より優れたものに仕上げ ることが求められる。

\section{4 - 2 . 国際共同研究の実施体制について}

進捗が順調で開発スピードが速い点から、研究代表者のリーダーシップがすぐれていると評価 できる。また、技術的なトラブルにも適切に対応している点などから、両国の研究機関の連携と プロジェクトマネジメントも、非常にすぐれていると判断できる。

供与機器の相手国への導入は順調であり、かつ既に有効に活用されているが、相手国での ODA 予算の執行ペースが早いため、相手国での研究開発費の確保が今後の課題である。

\section{$4-3$. 科学技術の発展と今後の研究について}

全般的に、研究の進め方は優れている。ガス化工程について、炭素 (C) 収支や熱収支をとり、 社会実装できる開発プロセスにブラシュアップする必要がある。社会実装に向けて、システム全 体としてのエネルギー収支の検討や、現地民間企業の参画等の活動を強化することか期待される。

本プロジェクトで開発中の技術は汎用性が高く、バイオマスエネルギーとしての利用だけでな 
くバイオリファイナリーの基盤となる技術として今後の展開が大いに期待できる。この分野で日 本の科学技術か世界をリードできれば、大きな価值がある。さらにバイオマスからジェット燃料 の生産が実現できれば、インパクトは非常に大きい。

相手国との交流、相手国への派遣など、人材育成が適切に進められている。日本側研究期機関 の学生に、現地での連続運転試験を分担させるなど、人材の育成が行われているが、タイ国側の 人材育成に比して十分ではない。

\section{4-4. 持続的研究活動等への貢献の見込みについて}

両国研究機関についてはプロジェクト以前から交流力盛んであり、本プロジェクトにおいても 安全性に十分配慮する必要のある大型実証実験を、共同で行っている点などか評価できる。今後 も継続的な発展か期待できる上に技術移転も進みつつあり、さらに強固な人的交流か期待できる。

半面、人的交流が個人的繋がりに依存し過ぎているため、新たなシナジー効果が出にくい点が 懸念される。両国研究機関の間でより組織的かつダイナミックな連携か取れ、相互啓発するよう な仕組みか期待される。

研究開発の持続的発展という面では、相手国の関心の高さと政策 $\left(A E D P^{1}\right)$ 、相手国研究機関の 研究体制、燃料合成への研究基盤などにより、今後の継続と展開か期待できる。原油価格が低迷 する状況か続く中、本技術によるバイオ燃料の事業化に向けた活動は簡単では無いと思われるが、 幅広い手段を検討しながら持続的に取り組むことが期待される。

\section{5 . 今後の課題・今後の研究者に対する要望事項}

今後残りの国際共同研究期間で成果目標を達成するために、下記の要望事項を参考にして今後 の進め方を検討して欲しい：

- 本課題で開発中の触媒技術は、大きな波及効果か期待できる基盤技術となり得るものであり、 バイオ燃料に止まらず、広くどのような応用が考えられるか、追求してもらいたい。また、 技術の本質が一般の人にもわかるように解説し、まとめて欲しい。

- 本研究で開発中の個々の要素技術は非常によく出来ているが、今後、システムや最終製品と しての競争力を高めるための努力が必要と考えられる。具体的には、プラントの規模やどの ようなバイオマスをどのように調達するか等のイメージをさらに明確にし、プロジェクト終 了時までに、経済性と $\mathrm{CO}_{2}$ 削減効果 (LCA) を明らかにするとともに、社会実装の道筋を明 らかにしていただきたい。

- ガス化プロセスについては、ロータリーキルン型ガス化炉という形式を採用し早期に実ガス での FT 合成を成功させた点を評価できるが、現行プロセスは熱バランスなどの面で大規模 プラント化には課題があると考えられる。また、バイオマスのガス化においてはタール生成 への対応か課題である。バイオマス種類とタール生成・除去、ガス精製技術については、将

1 タイ王国 代替エネルギー開発計画 (Altenative Energy Development Plan) 
来にも有益となるデータの蓄積を期待する。バイオマスの乾燥も含めて水蒸気をいかに効率 よく循環させるかといった課題も重要と考えられる。今後、社会実装に向けた評価をおこな いプログラムの課題をなるべく早めに具体化することを期待する。

- できれば、比較的競争力を発揮出来る可能性が高いといわれるジェット燃料への適用を検討 してほしい。

- 事業化の見通しと光のために解決すべき課題、対処方法、事業化のステップなどを詰めてほ しい。ジェット燃料などの新たな方向性を取り込むともに、産業界や政府の関与を強めるこ とか望ましい。

- 開発した要素技術のうち、他の分野に応用できるものがあれば、整理しておいてほしい。

- タイ国外で、原料となるバイオマス資源が得られる地域にも展開する可能性を検討してほし い。

- 日本側人材の育成については一層の強化を図ってほしい。

- 引き続き、安全管理について最大限の対策を行ってほしい。 
成果目標シート

\begin{tabular}{|c|c|}
\hline 研究課題名 & $\begin{array}{l}\text { バイオマス・廃棄物資源のスーパークリーンバイオ燃 } \\
\text { 料への触媒転換怵の開発 }\end{array}$ \\
\hline $\begin{array}{l}\text { 研究代表者名 } \\
\text { (所属機関) }\end{array}$ & $\begin{array}{l}\text { 椿 範立 } \\
\text { (国立大学法人 富山大学) }\end{array}$ \\
\hline 研究期間 & 平成28年度～平成33年度 \\
\hline $\begin{array}{l}\text { 相手国名/主 } \\
\text { 要相手国研究 } \\
\text { 機関 }\end{array}$ & $\begin{array}{l}\text { ター任国/チュラロンコン大学 } \\
\text { ター佦油公社、北部再生可能エネルギー }\end{array}$ \\
\hline
\end{tabular}

\section{付随的成果}

\begin{tabular}{|c|c|}
\hline $\begin{array}{l}\text { 日本政府、社 } \\
\text { 会，産業への } \\
\text { 筫献 }\end{array}$ & 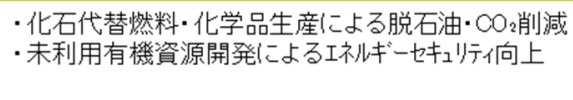 \\
\hline $\begin{array}{l}\text { 科学技術の発 } \\
\text { 展 }\end{array}$ & $\begin{array}{l}\cdot \mathrm{C} 1 \text { 化学·触媒化学転換技術 } の \text { 発展 } \\
\cdot \text { 化石代替燃料·化学品製造技術 } \omega \text { 発展 }\end{array}$ \\
\hline
\end{tabular}

展

知財の獲得、 .01 化学転換触媒技術(軽油代替燃料用F丁合成触媒

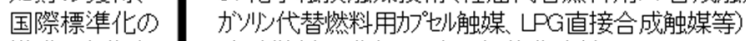

推進、生物資 ・バ仏燃料の分析・評価、規格化方法

$\begin{array}{ll} & \text { ・バ仏燃料の環境特性(LCA、排出ガス性状等) }\end{array}$

久等

世界で活躍で ・地球規模の資源・エネネギー問題および日本のエネルギー

きる本人久

きる早本人

技術及び人的

ネットワークの

構築

成果物(提言

書、論文、马

ログラ、

ニュアル

データなど) セ扯师向上に貢献できるグローバル人材の育成

・バ仏燃料のサプライチェーンバイ仏ス資源の生産・供給、

加工、転換、流通)を担う各主体間の連携構築
·研究者と成果の社会実装の担い手の連携構築

·次世代バ仏燃料製造に係る技術・人的补ワーク構築 ·大学間交流協定の深化、発展

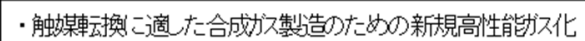

·高活性かつ実用性(低圧化等) (優れた

·がリリ代替然料製造に適たかプセル触媒

·化学品の脱石油に貢献する低温低圧姼人州合成

•バ仏 LPG製造に適したLPG直接合成触媒

・次世代バイオ燃料のLCA特性

\section{上位目標}

農業資源が豊富な新興国で未利用有機資源(バイオマスや低質炭等)を高品位な バイオ燃料・化学品に転換、化石資源代替·地球温暖化対策の加速化に貢献する。

事業化体制·製品利用スキームの構築など事業化への基盤が整う

（スケールアップ·低コスト化·規格化、石炭・天然ガスの利用 等）

プロジェクトE標

幅店い非可食系バイオマス資源 (木質·農産残さ·廃棄物系)から

化石代替(軽油・ガッリン・LPG等) となる高品位バイオ燃料·化学品製造技術を実証、 事業化システムや製品品質·価格·利用方法等の社会実装提案

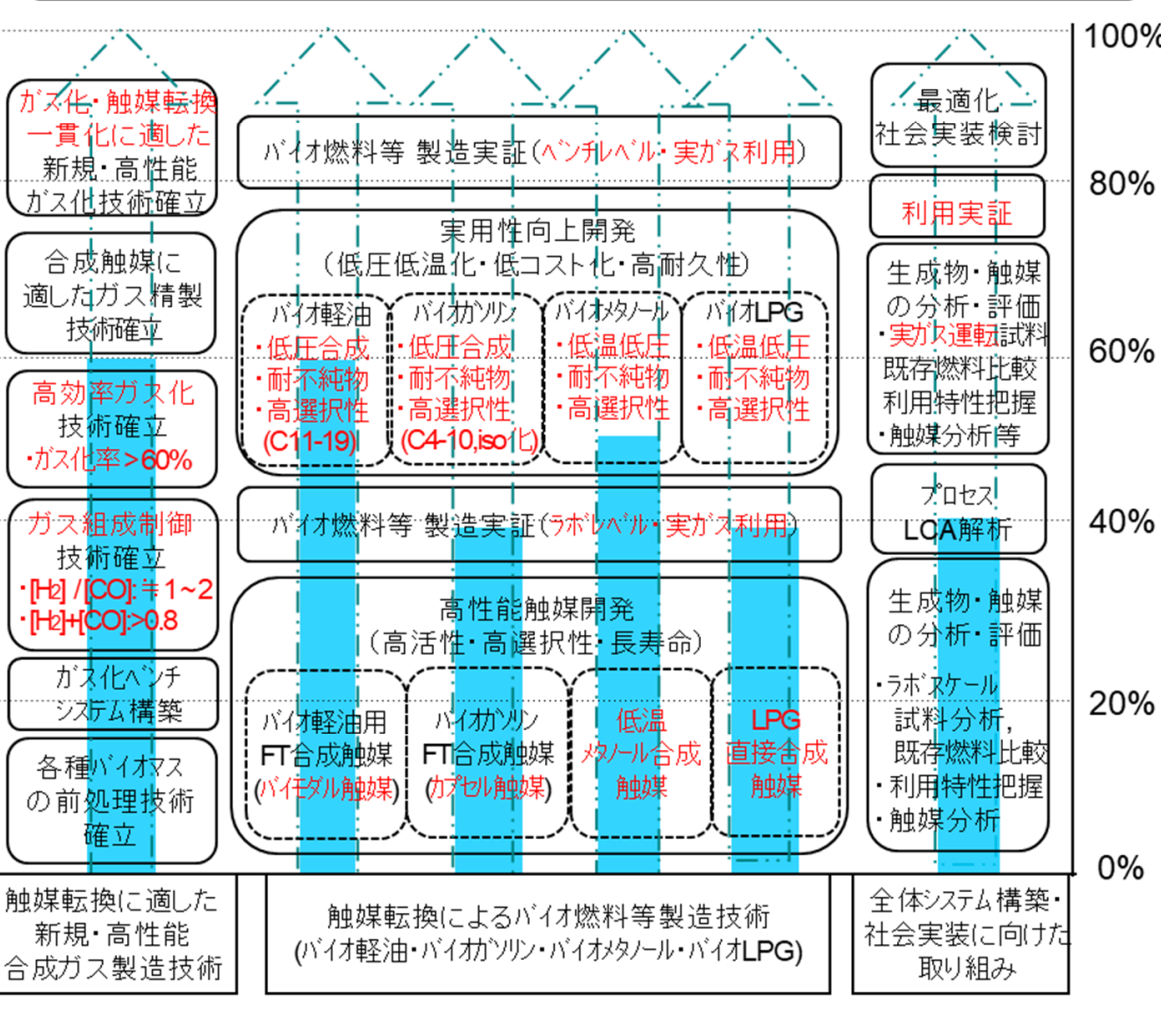

图 1 成果目標シートと達成状況（2019年 12 月時点） 